\title{
COUNTERTRADE AND THE CHOICE OF STRATEGIC TRADING FORMI
}

\author{
DAVID CAMIINO and CLARA CARDONE
}

Universidad Carlos III de Madrid. Spain

(First received Hardh 1995: accepted in revised form Fehrang 1997)

\begin{abstract}
Ahstract - Reciprocial trade agreements, usually known under the generic name of countertrade (CT) have been traditionally seen as a form of bilateralism. and thus as an inefficient form of international exchange. Although contemporary trade theories do not fully explain the increasing prevalence of CT transations, we will argue that it is possible to construct and use a third (hybrid) institutional form. which is congruent with the transaction-cost thenries, and we will show how - under market imperfections - countertrade can reduce transaction costs while conserving the efficiency galins generated by these specilic arrangements. (1) 1998 Elsevier Science Lid. Nll rights reserved
\end{abstract}

Key words: Barter, countertrake, transalction cost theory, asymmetric information, Iraling strategies.

\section{INTRODUCTION}

Reciprocal trade agreements such as countertrade represent a particular kind of institutional arrangement. A countertrade agreement has been defined ats "an international commercial operation in the framework of which the seller has to accept in partial or total setllement of his deliveries the supply of products coming from the purchasing country" (O):CD. 1981), In a world where most economic transactions involve either an actual or an electronic exchange of money for products, there would seem to be little place lor countertrade, "the most venerable form of exchange: a trade of one item for another" (Hammond. 1990, p. 2). It has been estimated. however, that at least between 10 and $20 \%$ of total world trade may be characierized as reciprocial trade (Hennart and Anderson. 1993, p. 6) and this proportion is still growing (Crinkotal et al., 1989, p. 494), apparently challenging the economic presumption that barter is less efficient than moncy-for-goods transactions.

Not all countries. however, demand compensation under the same circumstances: each type of countertrade can assume different patterns and is most likely to be motivated by different factors, since countertrade includes contracts of very different kinds. from simple barter to offset transactions. The term countertrade is therefore used to describe a variety of trade practices that can be categorized under two main headings:

(1) Barter and barter-type forms (c.g. switch trading and clearing arrangements): One contract. no money used and a long-term orientation that involves the swap of one or more products for other goods of similar value.

(2) Other contertertade forms, where money or credit are involved. such as:

- Counterpurchase: The exporter undertakes the purchase of goods and services from the country/company concerned. There are two separate contrats, the principal one normally paid for in eash or credit and the second in goods. 
- Compensation: Includes trade arrangements that are long-term in nature and consist of separate but linked money-for-goods contracts.

- Bay-Back: A form where the exporter transfers technology, and agrees to purchase in return some of the plant's output over a given number of years.

- Offser: The seller has to agree to subcontract some of the production to local producers, to increase its imports or to transfer technology.

Contemporary trade theories. however, do not fully explain reciprocal trade. since until recently the analysis of the contracts and institutions that govern it have been neglected (Marin and Schnitzer. 1995. p. 1049). Most international economists consider countertrade irrational and inefficient. or they see it as the result of government-imposed restrictions on trade and foreign exchange (see Hennart, 1993). In part this explanatory failure results from misconceptions about the different forms of countertrade and the polar question of internalization of transactions and market contracting.

In this paper we shall develop some theoretical elements for analysing the decision path for choosing forms for international trade. by examining alternative contracting forms. and asking ourselves why countertrade was preferred to market contracting or internalization. Two important elements in countertrade arrangements, namely thexibility, or the adaptive capability to switch from one trate or partner to another. and the tying of the two transactions to create a "hostage" (Williamson. 1983), will be the key to our analysis.

Following this introductory part, and in addition to a theoretical discussion. the paper first introduces an analysis of the economic rationale for countertracke, including the asymmetries of information and transaction-cost theory frameworks. Subsecuently. a conceptual moded analyses countertrade as a hybrid form between the market and the hierarchy. and examines the choice of countertrade as a strategic tradling form. The last section then provides a summary and some concluding remarks.

\section{I:CONOMIC RATIONALIE IFOR COUNTERTRADE:}

Among the oldest and most fundamental yuestions in economics are those regarding the use of media of exchange in international transiations. Traditional economic theory addresses the role and use of a medium of exchange to avoid trade frictions and proposes, essentially, that if money exists as a meatns of exchange, then barter appears irrational. Therefore. "ironically, what we call 'International Trade" is, in most instances, a cash transatetion and 'Countertrade', oddly enough, is what trade really meins in essence: an exchange of goods without the use of the currency" (Hammond, 1990, p. 2).

The analysis of countertrade has usually been conducted hy means of traditional economic theory, albeil based on simplified assumptions of perfect information*. Economic analysis works in an idealized world where economic systems run smoothly, and decisions regarding economic organization are based on production and/or distribution costs which can be easily identified. If economic friction in the form of transaction costs exists. then the explanatory power of traditional economic analysis is weakened since real-world situations do not always match economic predictions.

\footnotetext{
-Theoretical models of trade are always based on simplifying assumptions. The condition of perficet information postulated in the theory dexes not ellkerge spont:oneously. as most markets are imperfect to begin with (Scitovsky. 1906)).
} 
For such a market to be perfect, most of its members on the buying and selling sides would have to compete knowledgeably, and to do so they would have to assemble all the necessary information. Moreover, this assumption not only simplifies reality but also distorts it, because marketrelevant knowledge is not randomly distributed among market participants. but in most cases is biased in favour of one or the other side. Such a bias has a great impact on market behaviour and trade outcomes, and the resulting relationship is a well-known asymmetrical market situation.*

Although reciprocal trade is widely held to be uncompetitive. some authors regard it more favourably. To explain countertrade satisfactorily, the economic motivation for this preference needs to be revealed. An examination of the trading parties" incentives for bypassing money mediation suggests that. as the traditional case against barter was presented in the context of a closed economy, the extension of the argument to international trade implies that all trading partners should have equal access to the media of exchange and information. If this is not so. the theoretical case against barter does not hold up. and we are back to the basic tenet that some alternative form of reciprocal trade will arise. As Stigler (1969, p. 39) pointed out "the case for reciprocity arises when prices cannot be freely varied to meet supply and demand conditions. Here reciprocity restores flexibility of prices".

Reciprocal trade arrangements are often seen as a means of solving foreign exchange shortages when countries/customers have difficulty in obtaining trade credits, and most explanations of countertrade suggested in the descriptive literature ascribe the increasing importance of reciprocal trade to the high indebtedness of countries. Hennart (1989. pp. 131-132) has shown. however. that this is not generally true, and has in any case limited explanatory power. Perhaps only simple barter and barter-like contracts under specific conditions have this property, since they may not involve cash transactions of any kind (Banks, 1983). Other countertrade forms, such as compensation, counterpurchase and buy-back. which represent more than half of all countertrade transactions, do not help in solving a country's shortage of hard currency, and are more likely to be motivated by additional factors. $\dagger$

Empirical results (Hemnart, 1990; Caves and Marin, 1992; Hennart and Anderson. 1993) suggest that countertrate occurs in situations where the superiority of market-mediated transaletions is not well established, either because of asymmetric information or imperfect (distorted) competition. For both parties to countertrade there must therefore be compatible economic incentives to forego ordinary market alternatives. In the absence of these factors, countertrade would perhaps be replaced by money-mediated transactions in the form of commodity trade. forward sales, foreign direct investment (FDI) and other forms of internalization.

In many (regulated and developing ) economies, market imperfections are the norm and business skills are often scarce. while forcign exporters face many restrictions and a lack of information on the business environment and the quality of goods. We will see that under these circumstances countertrade may lead to transactions that would otherwise not occur. Studies by Hennart (1989) and Hennart and Anderson (1993). which also focus on transaction costs as a rationale for CT, lest the hypothesis that CT is a second-best alternative to direct foreign investment by looking at country data. They lind supporting evidence that CT is more frequently used by countries which restrict FDI. Their tests are based on 39 and 84 observations respectively.

\footnotetext{
*For a more detailed approach to the problems derived from quality uncertainty and the asymmetric information of buyers and sellers, see Akcrlof (1970).

+Non-price situations. like countertrade. can therefore assume many forms and consist in offering a great variety of linked transactions. including guarantics and warranties that combine the advantages of added information at a lower insurance cost.
} 
Mirus and Yeung (1986) used transaction-cost theories in an attempt to explain reciprocal trade. Defining countertrade as a "double coincidence of wants". "an incentive contract-output with quality dimension" and "a differentiated product used as an input by the technology supplier", they showed that the lack of foreign exchange was, at best, a partial and somewhat superficial explanation. The authors concluded that these arrangements did not necessarily imperfections. and resorting to countertrade may be a reflection of the high transaction and search costs faced by a trader when trying to market goods.

Further friction arises when goods are of uncertain quality, and when agents have different information about this quality. In this case some agents will make trade contingent on some information which they cannot observe. This creates an incentive problem, which in turn makes implicit credit arrangements difficult without a medium of exchange.

Murrell (1982) used market signalling theory to show that countertrade could solve problems that arose when the quality of foreign goods was unknown. He concluded that countertrade practices were particularly useful when a country has a poor reputation for quality, and when the information about the specific quality of products, which was important to the buyer. could not be obtained directly (here intermediate trading companies play a leading role). Predictions were supported by empirical tests based on data from more than $4(10)$ contracts.

There are two large areas of theoretical uncertainty surrounding countertrade and other reciprocal trade arrangements which this article will explore. The first is to account for the existence and use of countertrade as an intermediate (hybrid) arrangement. The contemporary theory of the firm emphasizes the cross-substitutihility of firms and markets as organizational modalities, but it does not easily explain intermediate organizations.* The second major area of incpuiry pursued here is an account of how countertrade agreements maintain their economic rents and stability. given the absence of legal-institutional supports.

\section{THII: INSTITUTIONAL. IRAMIIWOKK}

While the modern theory of the firm hats addressed the determinants of the internalization of economic transactions, a saltisfactory explanation of partial internalization remains elusive. A possible explanation may be "the difliculties one typically finds in confronting ideal types such as markets and hierarchies with the empirical richness of the wide variety of means for organizing transactions" (Collin and Larsson. 1993, p. 7). Nevertheless, since countertrade arrangements should not become a cattalogue of imperfect competition solutions in international finance and trading systems, the aim of this article is to approatch the economic organization of countertrade from a comparative institutional point of view, showing that it is possible to construct and use a third (hybrid) institutional form that is congruent with transaction-cost theory, while conserving efficiency gains generated by these specific arrangements.

Since the time of Williamson's (1975) original formulation, many criticism have ben levelled at the transaction-cost approach. $†$ The recognition that markets and hierarchies by no means constitute a mutually exhatstive set of institutional forms for governing transactions has generated "numerous attempts to develop alternative contracting forms" (Collin and Larsson. 1993, p. 5 ).

\footnotetext{
*Hennart (1093) has nevertheless argued that the two poles, firms and market contracting, in fict describe extreme and quite rate cases, with nost organizations falling somewhere between.

†Transaction-cost analysis is by no means the only explanation for the existence of firms. Efficiency reasons may lead to integration. permitting the realication of econnomics of sciale or scope. Firms may also be established to exert monopoly power (Tirsle, 1988).
} 
Williamson (1991), introduced the hybrid as an intermediate form between the market and the hierarchy. which involves regulation, franchising and various forms of long-term contracting. including reciprocal trading.

Unified-governance and market-governance are thus poles on the organizational continuum proposed by the transaction-cost theories, but other organizational hybrids have also been envisaged as middle-points on this continuum (Hennart. 1993) or as a third institutional form, with intermediate characteristics between the market and the hierarchy (Larsson, 1993). Discreet transactions would then be located at one extreme. while highly centralized hierarchical transactions would be at the other. and hybrid transactions (reciprocal trade and other forms of nonstandard contracting) would be located between them.*

Although many hypothetical forms of organization "never arise or quickly die out. because they combine inconsistent features" (Williamson, 1991. p. 271), complex arrangements such as joint ventures or countertrade agreements can be explained by invoking imperfect competition. We suggest here that countertrade is not novel, and by no means a mixed case, but that it is a dis-

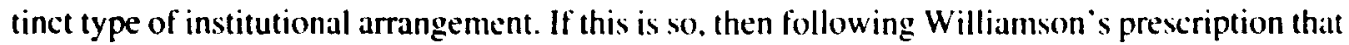
organizational forms are determined by a comparison of alternative institutional arrangements. we can say that the decision regarding the organizational form for coordinating international trade involves comparing at least three forms: (i) Market-contracting: (ii) hierarchy and (iii) intermediate forms ( such as countertrade).

In Williamson 's perspective, it is this efficiency criterion - the minimization of transaction costs - which explains the emergence of a specilic governance structure. Transaction-cost analysis entails an assessment of the comparative costs of planning. adapting and monitoring the completion of the task under alternative governance structures. This approach caln be extended in order to include hybrid forms, but the hasic postulate remains unchanged: the governance structure that finally emerges is the one that minimizes transaction costs.

Transaction-cost theory has been applied to many different business areals, and in this context appears particularly relevant to the study of the role of countertrade and other complex trading forms in the international business arena. since producers are likely to be concerned about the extent of the difficulties and costs involved in selecting. negotiating. manalging and controlling intermediaries in servicing foreign markets, which may be remote and complex (high uncertainty) and which recuire specialized knowledge and investments (high asset specificity).

Generally, the main determinant taken into alcount is asset-specificity (the level of uncertainty is assumed in some way). Consequently, agreements are supposed to minimize transaction costs when the degree of asset-specificity is located at an intermediary level. The underlying argument is that countertrade agreements combine some of the advantages of the market (high-powered incentives and less bureaucratic costs than hierarchy, but to a lesser degree than the market alternative) and the one hand. and some of the advantages of hierarchy (in terms of control instruments, reducing opportunism and information flows) on the other. This combination of advantages would be especially appropriate when the asset-specificity is not too high.

Under certain circumstances producers may think that relying on exports could be advantageous in the classical sense (production costs), but prohibitive in terms of transaction costs. In Williamson's terms. they might decide to use some kind of reciprocial trade agreement, rather

* In his earlier work. Williamson argued that hybrids could be expected to be rather rart. resembling the distribution of real-world organizations on the continuum of two peaks divided by a deep, broad valley. Laller Williamson revised his thinking. acknowledging that the population of complex economic organizations was far grealer than he had earlier thought, and that organizational forms were much more evenly distributed. 
than internalizing the export function or going to the market ti.e. through intermediaries or trading companies).

One way to deter this is to expand the contracting relationship from unilateral to bilateral exchange. Reciprocal trading. especially when it involves product exchanges. creates credible commitments that are signalled without exposing assets. Both parties understand that the transaction will be continued only if reciprocity is observed. Reciprocity can therefore generate benefits for the governance structure (Williamson. 1983).

Countertrade agreements have certain features reminiscent of markets. in that the two participating firms continue to conduct discrete exchanges with each other, while maintaining formally independent roles. Nevertheless. certain organization-like features are introduced as well: contractual limits are placed on the terms of the exchange. and overall limitations are set to govern activity with potentially competing firms. Within their areas of respective unilateral authority. the firms utilize their existing internal hierarchies to coordinate performance. A hybrid structure can he expected. when these conditions obtain.

Nevertheless. one importance source of sustainable rents is "the ability of firms to reduce the costs they experience in organizing both internal and external transactions below those of their rivals" (Hennart. 1994. p. 193) and to this end, costs are minimized when the firm chooses the organizing mode that is most efficient for a given transaction. The minimization of transaction costs is therefore a criterion of efficiency which explains the emergence of specific governance structures. i.e. either market or hierarchy, although this approach may be extended to include intermediate hybrid forms. The argument is thus that $\mathrm{CT}$ algreements offer prospective advantages over unilateral trade. if the resulting exposure of transaction-specific assels effects a credible commitment among the partmers. If stich is the case. we suggest that eountertrade can reduce transaction costs.

When strong uncertainty coexists with a high degree of asset-speciticity, however, it is impossible to specify ex-ante the whote set of contingent clituses required for exceuting the the contract (bounded rationality hypothesis). Thus contrats are necessarily incomplete. This in turn generates problems of enforcement, due to opportunism annong the agents. Consecpuently longterm incomplete contracting is generally characterised by frecpuent misunderstandings and conflicts which may lead to delays, breakdowns or other malfunctions. There are two main situations in which transaction costs are likely to be high:

- When there is significant information asymmetry between the partics;

- When the market is narrow because of scale economics, transportation costs or the need to make transatetion-specific investments.

According to Larsson (1993, p. 99) market contracting involves costs primarily for getting the products to and from the market. Under conditions of hierarchical coordination, on the other hand, such marketing and purchasing costs would be reduced to mere transportation costs. although there would be administrative expenses in addition to the internalization costs that are usually neglected in transaction-cost analysis. In the case of countertrade, however, the matin costs are related to the process of negotiation, and to achieving an agreement on a joint structure. as we shall see below.

Two observattions reinfore the idea that negotiation costs are important in the case of countertrade (barter) agreements. Firstly. agreements generally take the form of long-tern incomplete contracts, which are precisely those suffering from strategic bargaining. conflicts and other malfunctions, according to Williamson. Exhaustive contracting is too flexible and generally leads to 
Table 1. Tentative outline of a cripolar institutional framework

\begin{tabular}{llll}
\hline Institutional & Market & Countertrade & Hierarchy \\
\hline Division of adjustment & Self-adjustment & Joint adjustment & Imposed adjustment \\
Adjustment reference & Price & Contractual agreerments & Authoritative orders \\
Resulting from ... & Supply and demand & Negotiation & Planning \\
Primary relative costs & Marketing and purchasing & Searching and negotiation & Administration Internalization \\
\hline
\end{tabular}

Source: Adapted from Larsson. R. (1993. p. 99 ).

failure. Secondly, if we admit that the length of negotiations represents an acceptable approximation of the ex-ante costs, then it must be recognized that the latter are especially high: the duration of the negotiations often exceeds one year.*

Within countertrade transactions, however. free exchange is at least partly abandoned (perhaps due to concern about opportunism). but so too is total internalization. Rather, the two firms remain independent in their larger missions. but operate a specific pooling of assets through a joint governance structure and share their claim to the resulting residual. For transaction-cost theory the greater challenge is not to show which markets fail and why. but to show why a mix or intermediate structure (such as countertrade) may do more to minimize transaction costs compared to the alternative forms.

\section{THE MINIMIZATION OF TRANSACTION COSTS}

If countertrade does not appear to minimize transaction costs, i.e. if it is less efficient than hierarchy or market contracting. why do firms go in for it? What is the value of such agreements? How, in some instances, do they compensate for higher transaction costs? The answer is connected with the value of having a "hostage" in markets under asymmetric information and possessing the dynamic elements of countertrade agreements, ats a way of attaining future freedom of choice in unpredictahle or changing environments.

Most failures to explain countertrade may result from a misconception about the forms it may take. Hennart (1989, p. 148), for instance, argued that the various forms of CT are aggregated both in theoretical discussion and in empirical work. although in fact each one deserves an explanation on it own merits. Countertrade agreements include transatetions of very different kinds, some of them with barter-like characteristics such as (i) simple barter, switch trading and clearing arrangements, which may be a response to foreign exchange shortages or asymmetric information problems, while (ii) other countertrade forms (e.g. buy-back, counterpurchase and compensation), can be regarded under certain circumstances as a rational response to market imperfections - as a second-best option in al second-best world economy.

Although some specific ex-ante transaction costs may be high (searching, negotiating), the expost (bonding) effects and the consequences of executing the contract are of chief interest here. The problem in international trade is often that the quality of the goods is either not observed by an outsider, or can only be verified at considerable cost, so that it cannot be specified unambiguously in a contract. The CT contract is designed in such a way that goods serve as deal-specific

*The observations come from an examination of several casc studies of complex trade agrecments by Llerena ef al. (1991). 
collateral, and their value depends of the quality decision. Countertrade can provide an efficiency-enhancing way of dealing with problems of moral hazard in international trade. since the tying together of two transactions creates a "hostage" (Williamson. 1983) which may deter cheating on quality or defaulting on the payment of the original export.*

Commitment to the exchange is signalled more definitely by the willingness of the parties to accept reciprocal goods transactions. Reciprocity can serve to equalize the exposure of the parties, thereby reducing the incentive of one party to defect from the exchange, leaving the other to redeploy specialized assets at greatly reduced alternative value. Defection hazards are thereby reduced. giving the partner an incentive to fultil its financial obligations. $\dagger$ Countertrade creates a double moral-hazard situation. and is more likely to provide an efficient institution. the higher the gains from consecutive trades (Williamson. 1983).

Williamson views the firm as one of a set of possible institutional relationships structured in order to reduce the hazards of idiosyncratic bargaining that inevitably arise in various "small number" circumstances. such as asset-specificity and long-term contracts. While both bounded rationality and opportunism present difficulties. they do not necessarily lead to market failures. since markets represent "large number" conditions: there are many potential buyers and sellers of goods which are interchangeable: the market signals the appropriate price. "Small number" conditions are much more hazardous. Where the pool of potential transactors is limited, one party can gain the advantage. Where the exchanged assets are no longer obtainable from multiple sources, but are unique, tension can be expected between buyers and sellers. If the seller has no alternative customer for the product, he maly be constrained to aceept a price irom the buyer which is not adeyuately compensated. Similarly, the purchaser may be dependent on the supplier of a unique or scarce asset, and significant costs and delays may be incurred if the desired good is to be obtained from an allernative supplier. Similar dynamics of mutual dependency can be observed in long-term countertrade relationships.

Another assumption is important here, namely opportunism. If there is no opportunism, good fath and mutual adjustment can be used for coordination purposes, and salieguards will be superfluous under these circumstances. Not all situations and individuals, however, are opportunistic to the same degree, "some individuals are opportunistic and [...] diflerential trustworthiness is rarely transparcnt ex-amte'. As a consequence, ex-ante screening efforts are made and ex-post safeguards are created" (Williamson, 1985 p. 64) $\ddagger$.

From the production point of view, the idea of an organization without boundaries implies the coordination of relations with supplicrs and customers by assuming an integrated view of the system. The development of institutional trade agreements, such as countertrade, will thus help to reduce the risk of opportunism. Under these circumstances, buy-back, counterpurchase and other compensation agreements can be seen as attempts to reduce transaction costs by providing what amounts to a bond or hostage.

In CT costs are usually highly specific to the transaction, and have two attributes: they are incurred in advance of the contemplated exchange, and their value in alternative uses or by alternative users is greatly reduced (Klein et al., 1990 used the term "appropriable quasi-rent" to

\footnotetext{
*The crucial assumption underlying the analysix presented in this article is that, as assets become more specific and appropriable, quasi-rents are created (thus increasing the possible gains from opportunistic behaviour), the costs of market contracting will generally increase more than the costs of ecountertrading.

+"Reputation theory" suggests that a country will not repudiate its debt. if it would ctherwise risk its future participation in the international trade and financial markets. ¥Quoted by Nexorderhaven ( 1995 , p. 47).
} 
describe this condition). Reciprocity in these circumstances is thus a device whereby the continuity of a specific trading relation is promoted. white also reducing risk. In the absence of a "hostage" or some other assurance that the other party will not defect, the sale may never materialize. Thus. barter may be an "inefficient" form of trade, not because of the absence of a "double coincidence of wants" but as a result of asymmetric information and market inefficiencies.

Although we explore one particular cost of using the market system - namely the possibility of postcontractual opportunistic behaviour - another key dimension in this context is asset specificity, which refers to "the dependence created through transaction-specific investments. It expresses the amount of value involved in the exchange as such. This value arises from the parties having made investments in the exchange. and from the cost that would be incurred through ending the relation and choosing another exchange party. The second dimension is uncertainty. inherent in situations in which bounded rationality makes humans incapable of predicting the future. The third dimension is frequency, referring to how often the transaction occurs" (Collin and Larsson. 1993, p. 4).

At this stage we are able to analyse the limitations of transaction-cost explanations in the case of countertrade agreements. Countertrade seems to suffer high transaction costs, partly because of its neglect of the flexibility aspects. The nature of the flexibility considered will be crucial to our analysis. Indeed, in economic theory it is usually considered that flexibility is a market characteristic: market mechanisms insure a certain kind of flexibility (through price and/or quantity adjustments). mainly in terms of resource allocation. Hierarchies, on the contrary. are supposed to be "rigid". Rigidities are the result of bureaucratization and are centralized decision processes, and linked to the size and complexity of the hierarchy.

Flexibility is an ubiquitous and rather ambiguous concept. The kind of flexibility we are talking about must be clearly distinguished from the allocative mechanistic adjustment properties generally attributed to market transalctions. We do not argue that countertrade agreements are more llexible than market transactions, but that they have some of the properties of market adjustment, like the ability to change partners or dissolve the relationship in case of opportunistic behaviour.*

The transaction-costs approach is essentially a comparatively static one: the institutional analysis assumes instantaneous optimization of the institutional form according to a specified set of determinants - for instance, the degree of asset-specificity - and the process of shifting from one particular form to another is not analysed. In this context a hybrid arrangement permits a more appropriate approach to organizational alternatives: barter and barter-like agreements may then appear as intermediate forms, more tlexible than hicrarchies but less than markets.

Other countertrade arrangements can instead be used as devices for reducing the high Iransaction costs, which affect three types of international transactions in particular, namely the purchase of poorly protected technology, the sale of intermediate products under small-number conditions, and the purchase of marketing services when the distributor has to make up-front transaction-specific investments in countries with restrictions on incoming FDI.

A tirm motivated by a desire to integrate horizontally or vertically, or to benefit from firmspecific advantages, would want to put its capital and technology to use in production abroad. However, due to high proprietary costs and political constraints it may be prevented from

*Opportunistic behaviour has been identiticed and discussed in modern analysis of the organization of economic activity. Williamson (1975), for example, has referred to the effects on the contracting process of "ex-post small numbers opportunism". 
assuming ownership. In this situation the imperfections in the markets for capital and technology are not overcome by internalization, which leads to a divergence between the economic interests of the user and supplier of capital and technology. This problem is aggravated by the information asymmetry between the user and the supplier, and by the absence of future commodity markets in many countries and goods.

The main alternative to vertical integration as a solution to the general problem of opportunistic behaviour is some form of economically enforceable long-term contract. such as a countertrade agreement. Clearly a short-term (i.e. one transaction, non-repeat spot sale) contract will not solve the problem (Klein et al., 1990). The relevant question then concerns when the vertical integration, the market contracting or the countertrade transactions will occur. We will attempt to make a distinction between a non-price long-term contract like countertrade, and ownership. or market contracting.

Non-price long-term contracts used as an alternative to market contracting or vertical integration can be assumed to assume one of two forms: (i) an explicitly stated contractual guarantee legally enforced by the government or some other outside institution: or (ii) an implicit contractual guarantee enforced by the market mechanism of withdrawing future business is opportunistic behaviour occurs.

Explicit long-term contracts can in principle solve opportunistic problems but, as we have already suggested. the solutions are very costly. Contractual provisions specifying compulsory arbitration or more directly imposing costs on the opportunistic party (for example. via bonding) are alternatives often employed to cut down on litigation costs and to create flexibility without specifying every possible contingency and quality dimension of the transaction.

Such countertrade agreements thus arise as a rational economic solution to market imperfections caused by high ownership costs (or ownership constraints) and information asymmetry. This means that most of these alternative institutional forms for countertrade can be ascribed features which lic between those of the market and those of the hierarchy. Buy-back, for instance, involves a class of international transalction that can be viewed as the vertical or horizontal integration of economic activities while retaining separate ownership, whereas offset has been used in government-related contracts (fighter aircraft, military supplies, etc.) largely in response to political factors.

The analysis has two important implications: first, since a significant percentage of countertrade transactions have little to do with foreign exchange shortages, changes in the debt situation of less-developed countries should have only a moderate impact on the development of countertrade. Second, the future of counterpurchase, compensation and buy-back depends ion restrictions on FDI on the part of the host countries.

Since buy-back, compensation and counterpurchase agreements probably make up more than half of all countertrade transactions, the countertrade intensity with a country should be correlated with the degree to which it restricts incoming FDI. The empirical evidence generally confirms these observations (Hennart, 1989, p. 147). On this point the analysis links countertrade to existing theories of FDI.

Countertrade can also be seen as a device for reducing the cost of arranging for the international marketing of products. There is clear evidence that countries imposing counterpurchase requirements do so in order to diversify their exports. There are two ways in which manufacturing and overseas distributions can be integrated. Manufacturers in the home market can establish sales subsidiaries overseas, or firms with developed distribution systems in the home market can establish production facilities in foreign countries. 
Distribution services are also subject to market failure. First. there is often a small number of potential suppliers of distribution services. Second, there is substantial up-front investment to be made in developing distribution structures, which gives rise to a specific asset. Finally, distributors have local knowledge (about their territories), on which it is difficult to set as price.

In addition, producers may feel uncomfortable with export partners who have access to sources of information unavailable to them selves (asymmetric information), who do not necessarily enjoy the best reputation (perhaps due to past opportunism), or who are operating in a business environment where reliance on export intermediaries may not have been traditionally encouraged, in general. and particularly not by government (atmosphere).

In order to explain the nature of the agreements as stable strategies, we use the notion of organizational flexibility, based on the activation of learning activities between the countertrade partners, which the transaction-costs explanations failed to consider. Such agreements are thus a response related to the value of the dynamic elements of countertrade agreements, as a means of learning and enhancing one's future freedom of choice in unpredictable or changing environments. Countertrade then, can be considered as a routine process for creating complex agreements. constituting a particular kind of institutional trading form.

Even if reciprocal trade agreements suffer high ex-ante transaction costs due to the lengthy negotiations. the traditional approach to CT - because of its neglect of the dynamic aspects is unable to explain the positive value of such agreements. This line of thought thus suggests that barter and barter-like trading agreements will be useful in situations where due to information asymmetry. high transaction costs would otherwise prevent international trade from taking place; other countertrade forms such as buy-back, compensation and counterpurchase, on the other hand, will be used to avoid restrictions on exports and to deal with the problem of moral hazard when host countries have restrictions on FDI.

In conclusion, thee seems to be evidence that although the negotiation costs of countertrade agreements are often high, such complex contracts may - in terms of efficiency gains and organizational tlexibility, and in the absence of equity links - a second-best answer to the problems of marketing and investing in foreign markets. The analysis of countertrade has thus progressed from a simple situation of double coincidence of wants, to a double coincidence of information scarcity. It is not then necessarily an inefficient form of trade, nor is it inevitably a reflection of a shortage of foreign exchange; countertrade is simply a substitute for other more standard forms of market trade or internalization.

\section{THE CHOICE OF STRATEGIC TRADING FORM}

Countertrade arrangements represent only one of the options available to the exporter for market entry or the maintenance of market shares. There are other alternatives such as licensing. plant delivery, co-production, subcontracting. joint-venture, joint tendering and bilateral or tripartite governance forms (see Buckley and Casson, 1988 or Hennart, 1988). China is an obvious example, where buy-back agreements have recently been declining with the enactment of joint-venture regulations. Some countertrade forms can then be seen as a hybrid of joint venture, franchising, vertical integration and FDI under political and ownership constraints.

The organizational decision to establish a countertrade transaction can be more usefully envisaged as a set of sub-decisions, including (i) where to locate various stages of production; (ii) where to locate the boundary between the firm and the exterior; and (iii) whether the organizational boundary should be hard (market-contracting) or soft (internalization). For a host 
of environmental and institutional reasons, these boundaries often correspond to national market frontiers in countertrade arrangements.

The decision as to where to locate specific production phases is dictated by locational advantages.* Advantage may be viewed in terms of returns on productive assets. Assets - be they plant. labour. or distribution channels - which are located in economies characterized by comparative advantage, are more favorably priced.

Complex production may involve distributing production phases over different national territories (that is, by using productive assets located in different national territories). This decision corresponds to identifying the national economy which has a comparative advantage during a particular production phase. Alternatively this may be thought of as commanding (through "transactions") the optional set of immobile productive assets. Multinational companies may be particularly adept at identifying which national economy has a comparative advantage in a particular stage of production.

Given that the optional organizational structure frequently requires a transnational distribution of production. the analysis then proceeds to the internalization/market decision. According to Williamson, this involves a comparative analysis of institutional forms. with internalization being favoured where market transaction costs are relatively high (or equivalent, where markets fiil). Similarly, given a transnational distribution of production, internalization in the form of FDI. is preferred where the firms possess firm-specific advantages which they prefer not to alienate, and countertrade is used when these advantages are shared.

The main aspect to emphasize is the reconfiguration of organizational boundaries. The spread of subcontracting and other forms of interfirm agreements - from joint ventures to strategic alliances - has developed network form of organization as a third institutional form. somewhere half-waly between vertical integration and markel contracting. A hybrid form of governance is likely (o) arise, as such a development may be the tinal outcome of a long process started from the polar premises of make-or-buy decisions (Williamson. 1975).

Hybrid governance, with safeguards, corresponds to bilateral or trilateral governance as described by Williamson (1985, 1991). "These relationships are characterized by high levels of asset specificity and mutual adaptation and $\mid .$. . can take the form of complex contracts, specifying arrangements for price and quantity adjustments . . " (Noorderhaven. 1995. p. 45). International countertrade agreements, we believe, are organizational hybrids, intermediate points on the continuum described by Williamson (1991) and others, between markets and complete integration (the unitary firm). The organizational decision is more complex than deciding whether a firm purchases a productive asset (internalization), or its output (market). We describe this more complex decision as an "access decision". in which internalization is only one of a larger set of possibilities.

There are situations in which $C T$ alternatives maly be beneficial to partners, because economies can be realized. Let us take the example of a producer of textile machinery who exports to a country like China. If the exporter firm agrees to take payment in the form of textile products (buyback), it may reduce the risk of variability in product quality and delivery schedules (as a result of its own technology and management), and the Chinese may perceive a lower risk of product

\footnotetext{
*In his "eclectic" approuch, Dunning (1988) translates the Hecksher-Ohlin notion of comparative advantage, which is an attribute of a national coonomy, into "locational advantage". Locational advantage is not directly attached to a territory, but rather to certain productive assets fixed to that territory. The immobility of productive assets (such as labour) underlies this motion of Ioxational advantage.
} 
Table 2. Choice of strategic trading form

\begin{tabular}{lll}
\hline Access & \multicolumn{1}{c}{$\begin{array}{c}\text { International Trade Commitments } \\
\text { Spot (Cash/CrediUno money) }\end{array}$} & Continuous (Contracts) \\
\hline $\begin{array}{l}\text { Exclusive } \\
\text { Shared }\end{array}$ & $\begin{array}{l}\text { Barter and barter-type forms } \\
\text { Market }\end{array}$ & $\begin{array}{l}\text { Intemalization } \\
\text { Other countertrade forms }\end{array}$ \\
\hline
\end{tabular}

Source: Adapted from Atik. J. (1993).

failure in buying the machinery, since the selling firm will not be "paid" unless the machinery performs to specifications (Rugman and Hodgetts. 1995.p. 168).

Assume, however, that the home country restricts incoming FDI, and is either unable or unwilling to set up marketing networks abroad. Compensation and counterpurchase can serve as the next best route to effective marketing. By telling suppliers that they will import only if the supplier takes back and markets their products, countertraders can force suppliers to undertake marketing investments which they would not otherwise have done. The exporter who is foreed to take back the countertrading country's products can be expected to make a greater commitment to marketing the goods, because failure to do so would jeopardize his future sales. This is a way of substituting for hierarchical coordination, when the political desire for national sovereignty pushes towards inflows of FDI.

As we have suggested above, each viable form of governance - market, hybrid forms such as countertrade, hierarchy - is defined by a series of attributes that bear supporting relations. Among the intermediate forms, countertrade may be a superior structure when it comes to exploiting special tratding situations, where (i) the prospect of market failure makes spotcontracting unreliable; (ii) access to assets can be viably shared without general diffusion; but where (iii) greater attention must be paid to preserving economic rents (Atik. 199.3).

A firm must obtain aceess to all the necessary traded assets: "transalctions" are the exchanges by which such atceess is obtained.* The alceess decision includes (i) whether recourse to the asset is on a spot (murket-cash/credit or barter-no money) or a continuous (contracting) batsis, and further, whether (ii) such access is to be exclusive or shared.

Nole that the spot/continuous access decision follows Williamson's "fundamental transformattion": where markets function well, spot aceess is adequate; where markets fail (small numbers) continuous use is preferred in order to reduce opponunism. Consider the following matrix:

The framework includes two dimensions by which access to traded goods are obtained. The first dimension expresses whether access to an input/output is on a spot or a long-term continuous basis; this line of analysis is consistent with transaction-cost theory. The second dimension decides whether access to the goods may he shared without destroying economic rents.

Deciding what form of countertrade to use for entering up on an international transaction is more complex than the usually proposed decision between firm or market. Barter contracts reached under these circumstinces are called spot-market contracts, beciuse they govern goods or services that are to be exchanged "on the spot". For more complex transatetions that extend

\footnotetext{
"Hennart ( $(\mathcal{W})$ ) distinguishes metheds of organization (price syskem is. hierarchy) from institutional choice. Thus, even when a polar institutional form is used, a mix of organizational methods will often be observed. A market transaction will predominantly rely on the price system. but may have hicrarchical features (i.e. hehavioural controls) as well.
} 
over time a relational form of contracting. which does not attempt the impossible task of exclusive contracting but settles instead for an agreement that frames the relationship. other $C T$ forms may be more suitable. Again. continuous access to an asset will be sought where opportunism appears likely to arise; ownership of a productive asset (internalization) or longterm production contracts (buy-back. counterpurchase, etc.) necessarily provides continuous access.

However, there is another important dimension to consider: whether the access to the traded asset is exclusive or may be shared. If the spot versus continuous access decision reflects a minimization of transaction costs, then the shared/exclusive access decision is driven by the desire to preserve imperfect competition. This matrix is thus perhaps more "eclectic" than the more purely transaction-cost explanations (Atik, 1993).

A firm demands exclusive access to those assets which generate competitive advantages: proprietary technologies are the prime examples of such assets.* Other non-strategic assets may be profitably shared without dissipating rents. Certain goods, however, are best exploited through joint access, where by a limited number of firms share their use but jointly withhold use from all other market participants. $\dagger$

A long-term countertrade contract is thus on the same basis us ownership, providing continuous access to an asset. just as both ownership and long-term contracts suppress the need to bargain over a longer period. On the other hand, barter and barter-type methods, for instance, arise because what appears to be shared use is in fact a spot transaction, with simultaneous exclusive aceess to the assets for the companies involved. Trade arrangements implying reciprocity can also be used to equalize the exposure of the parties. Other countertrade forms (buy-back, counterpurchase, etc.) represent particular triding arrangements. They occur when (i) access to an asset is to be continuous : when (ii) shared access is more efficient than exclusive aceess; but when (iii) countertrade is preferred to the market mechanism.

\section{SUMMARY AND CONCL,UDING REMARKS}

One of the most important developments in international trade over the last two decades has been the increase and widespread use of barter-like practices, usually known under the generic name of countertrade. According to economic theory, if moncy exists as a means of exchange, then given the superiority of money-mediated transactions, barter would be irrational.

Competing theories arise, however, when it comes to explaining reciprocal trade under both perfect and imperfect competition. Several authors have attempted to explain the presence and increasing prevalence of these complex forms of international transactions, using the standard tools of economic analysis. They show that in many circumstances countertrade is a rational response to transaction costs, information asymmetries, moral hazard/agency problems and other market imperfections. simply representing a substitute for other more standard forms of market trade or internalization aimed at reducing transaction costs under the conditions outlined.

\footnotetext{
*As Dunning (1988) points out, the ownership of an asset is not irrelevant to its value. This makes an explicit link between ownership and leciational advantage.

†Shared use. it seems, can minimize transaction costs in certain circumstances. while simultaneously conversing the economic rents which these specific productive assets generatc (Kogut. 1988, pp. 319-320).
} 
In this article we have looked at economic countertrade arrangements from a comparative institutional point of view, whereby cutting down transaction costs is seen as the key feature of this form of strategic trading. We argue that countertrade is not novel: nor is it a mixed case. Rather. it is a distinct type of institutional arrangement. Consequently in the organizational continuum proposed by Williamson it is possible to construct and use a third (hybrid) institutional form which is congruent with transaction-cost theory.

Hence, what distinguishes these complex forms of trading arrangements is the kind of transaction effected (reciprocal trade), and the reason why they can minimize transaction costs more than internalization and market contracting. Each viable form of governance - market, hybrid (countertrade), hierarchy - is defined by a series of attributes that bear a supporting relationship.

This line of thought suggests that barter and barter-like trading agreements will be useful in situations where, due to asymmetric information, high transaction costs would otherwise prevent international trade from taking place. Other forms of countertrade such as buy-back. compensation and counterpurchase on the other hand will be used to avoid restrictions on FDI by host countries. In this context two of the most common forms of countertrade, compensation and counterpurchase. can be explained as attempts to build up reciprocity in order to reduce transaction costs in the international marketplace for intermediate products, technology and distribution services. Reciprocity can also be used to equalize the exposure of the parties in the case of buy-back agreements.

Due to incomplete contracting or the absence of law enforcement, international trade imposes the great risk of opportunistic behaviour on the part of trading partners. Countertrade is supposed to solve the moral-hazard problem by introducing a "hostage", which would be forfeit - at any rate partly - if either party chcats during the first transaction. For this construction to work the hostage has to be sufficiently valuable compared with the possible benefits of cheating.

In order to explain agreements in terms of stable strategies we also developed the concept of organizational flexibility, based on the activation of learning activities between the countertrade partners - something which the transaction-cost explanation failed to consider. The choice of trading form is thus a response related to the value of the dynamic elements of countertrade agreements as a means of learning and to increase future freedom of choice in unpredictable or changing environments. Countertrade will then be regarded as a routine process of creating complex agreements which constitute an institutional an institutional trading form.

Barter and barter-type transactions can be explained in a framework where by access to the traded goods is on a spot but also an exclusive basis - a species of mutually exclusive spot contract in which no money is used. Other countertrade forms can be explained instead in that access to an input-output is continuous but can be shared without destroying economic rents.

Nevertheless, although "Considerable progress has been made in the last two years in developing a theory of institutional choice based on the minimization of organizing costs" (Hennart. 1994, p. 193), we do not claim to have presented a general theory of countertrade. Rather, we argue that some countertrade forms may often a superior trading structure for exploiting special situations, where (i) the prospect of market failure means that spot contracting is unreliable; where (ii) access to assets can be viably shared without general diffusion; but where (iii) greater attention must be paid to preserving economic rents derived from the benefits of organizational flexibility.

We therefore conclude that under certain circumstances - such as asymmetric information, host country restrictions on foreign investment, a rapidly changing environment - barter-like agreements and other forms of countertrade can represent a form of that minimizes transaction costs while also conserving the economic rents generated by these specific arrangements. 
Acknowledgements - The authors would like to thank Jeffery Atik and Salvador Carmona for their useful ideas. comments and support in reviewing an earlier version of this paper. Any possible mistakes are, of course, the sole responsibility of the authors.

\section{REFERENCES}

Akerlof, G. (1970) The market for lemons: Quality uncertainty and the market mechanism. Quarterly Journal of Economics 64. 488-500.

Atik. J. (1993) Technology and distribution as organizational elements within intemational strategic alliances. Journal of International Business Law 14. 273-313.

Buckley. P.J. (1983) New theories of international business: some unresolved issues. The Growth of Intemational Business. Mark Casson.

Buckley, P. J. and Casson, M. (1988) A theory of co-operation in international business. Management International Review 28. 19-38.

Caves. R. and Marin, D. (1992) Countertrade transactions: theory and evidence. The Economic Journal 102. 1171-1183.

Collin. S. and Larsson. R. (1993) Beyond Markets and Hierarchies. International Studies of Management and Organization 23(1), 3-12.

Contractor. F. J. and Lorange. F. (1988) Why should firms cooperate? The strategy and economic basis for cooperative ventures. In Cooperative Strategies in International Business. ed. Contractor and Lorange.

Czinkota. M.. Rivoli. P. and Ronkainen. I. (1989) International Business. The Dryden Press. New York.

Daniels. J. and Radebauch. L. (1991) International Business: Environment and Operations, 6th edition. Addison-Wesley. Reading. MA.

Dunning. J. H. (1988) The Eclectic Paradigm of International Production: A Restatement and Some Possible Extensions. Journal of International Beasiness Studie's 19(1). 1-31.

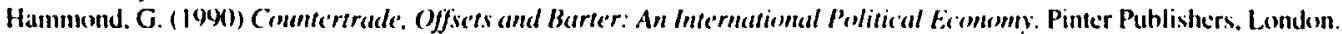

Hennart, J. F. (1988) A transaction costs theory of equity joint ventures. Strategic Manage'me'ns Journal 9(9)), 361-374.

Hennart, J. F. (1989) The transaction-cost rationale for countertrade. Jonornal of law. Eeomomics and Orgamiantions $5(1)$. $127-153$.

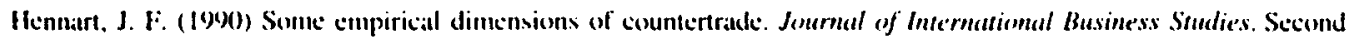
Quarter, 24.3-270.

Hennart, J. F. (1993) Explaining the 'swollen middle': why most transatctions are a mix of market and hicrarchy.

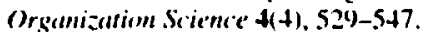

Hennart. J. F. (1994) The 'Comparative institutional' theory of the firm: some implications for corporate stratlegy. Jourmal of Monege'ment Sindie's 31(2) 193-207.

Hennart, J. F. and Anderson, E. (1993) Countertrade and the minimization of transatction costs: an empirical examination. Jonurnal of Lam: Economicx and Organisations, 9(2), 29(2-313.

Klein, B., Crawfiord, K. G. and Alchian, A. A. (1900) Vertical Integrattion, Appropriable Rents, and the Competitive Contracting Process. The Journal of law and Ecomomics 21, 207-326.

Kogut, B. (1988) Joint-Ventures: Theoretical and empirical perspectives. Sitrategic Matmagement Journal 9, 319-320.

Larsson, R. (1993) The handshake between invisible and visible hands. Internatiomal Studies of Managemeen and Orgamization 23(1),87-116.

Llerena. P. Umbhatuer. G. Wolff. S. and Yildizoglu. M. (199) 1) Rapport final: Accords de coeperation inter enterprises dans le secteur des télectommunications. Beta-ULP. Strasbourg.

Marin, D. and Schnither, M. (1945) Tying trade flows: a theory of countertrade with evidence. The American Economic Review 8515), 1047-64.

Menzler-Hokkanen. I. (1989) Countertrade arrangements in international trade: A tool for creating competitive advanlage? Scandination Journat of Mamagement 5(2), 105-122.

Mirus, R. and Yeung. H. (1986) Economic incentives for countertrade. Journal of Imernational Business Siudies Fall. 27-39.

Murrell, P. (1982) Product quality. markct signaling and the development of east-west trade. Ecomomic Impuing 20(4). $589-603$.

Neorderhaven, N. G. (1945) Transaction, interaction, institutionalization: toward a dynamic theory of hybrid governance. Srandinavion Journal of Management 11(1), 4.3-55.

Oryanization for Economic Coxperation and Developonent (1981) East-West Trade: Recent Developmems in Coumterirade. OF:CD. Paris.

Ruginan. A. and Hexlgets, R. (1995) International Business. A Strategic Manageme'nt Approach. McGraw Hill, New York.

Scitovsky, T. (1990) The benefits of asymunetric markets. The Jenurnal of Ecomomic Perspectives $4.135-148$.

Stigler. G. (1969) President's task force on productivity and competition. Trude Re'gulution Reporter. 419.

Tirole. J. (1988) The Theorn of Indusirial Organization. MIT Press. Cambridge, MA. 
Williamson. O. (1975) Markets and Hierurchies: Analysis and Antitrust Implications. Free Press. New York.

Williamson. O. (1983) Credible commitments: using hostages to support exchange. The American Economic Review $73(+1.519-540$.

Williarnson. O. (1985) The Economic Institutions of capitalism: firms, markets, relational contracting. The Free Press, New York.

Williamson. O. (1991) Comparative economic organization: the analysis of discrete structural alternatives. Administrative Science Quarterly 36, 269-296. 